\title{
Effect of blended learning, motivation, study hour on student learning achievement
}

Jaka Sunardi $^{1}{ }^{*}$, Soh Kim Geok ${ }^{2}$, Komarudin ${ }^{1}$, Hari Yuliarto ${ }^{1}$, Ranintya Meikahani ${ }^{1}$

${ }^{1}$ Universitas Negeri Yogyakarta. Jalan Colombo No. 1, Yogyakarta 55281, Indonesia.

${ }^{2}$ Faculty of Educational Studies, University Putra Malaysia, Serdang, Malaysia.

* Corresponding Author. Email: jaka_sunardi@uny.ac.id

Received: April 30, 2021; Accepted: September 2, 2021; Published: September 25, 2021

\begin{abstract}
This research aims at determining the effect of blended learning, motivation, lesson hour on student achievement.The research method used is a survey method, with data collection techniques using a questionnaire. The population in this study were students of the Health and Recreation Physical Education Study Program, with a total of 221 UNY students and 188 UPM students. The data analysis technique used regression test. The results showed that (1) There was a significant influence between blended learning on the motivation of UNY and UPM students, (2) There was a significant influence between blended learning on the learning hours of UNY and UPM students, (3) There was a significant influence between blended learning on study hours of YSU and UPM students, (3) There is a significant influence between blended learning on the learning motivation of UNY and UPM students. There is a significant influence between blended learning on learning hours for both UNY and UPM students, (4) There is an influence between blended learning on student learning achievement even though it is weak, this shows that learning achievement is influenced by other variables not studied. Whereas for UPM there is a significant effect, but for the learning achievement variable it is influenced by other variables that are not researched, (5) There is a combined effect of blended learning, motivation, and study hours on UNY and UPM students, but the learning achievement variable is influenced by other factors or variables not studied.
\end{abstract}

Keywords: blended learning, motivation, study hour, learning achievement

How to Cite: Sunardi, J., Geok S.K., Komarudin, K., Yuliarto, H., \& Meikahani, R. (2021). Effect of Blended Learning, Motivation, Study Hour on Student Learning Achievement. Jurnal Keolahragaan, 9 (2), 168-177. doi:https://doi.org/10.21831/jk.v9i2.40508

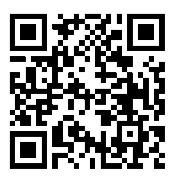

\section{INTRODUCTION}

The development of science and technology in various fields create a lot of changes, especially in improving the quality of education. Many factors affect the development of education in the future, one of which is the rapid development of information technology. The development of technology in global era has significantly changes, it is marked by the emergence of fierce competition in obtaining jobs that demand competence in mastering technology. At the beginning of the emergence of computerized technology, limited human resources were the main factors that hindered interaction between humans and computers (Sucipto \& Widiyanto, 2016, p. 179). While the most important component in the learning process both conventionally and by utilizing technology is HR (Rivalina, 2005, p. 133).

Globalization has changed these dynamics, sometimes in powerful ways. In this context, the reformation in the field of education and learning need to be carried out continuously, it is a process that never stops. Competency-based education is an example of the results of thus reformation with the aim of improving the quality of education and learning. Developing and supporting students' technological competencies is a key element of schools (Selwyn \& Husen, 2010). Education must also be able to deliver each individual to survive, be competitive, independently in a dynamic life and move fast in competition (Sucipto \& Widiyanto, 2016, p. 128). Another factor in the success of education is the factor of educators, teachers, lecturers, are educational staff and participate in providing education (Pambudi $\&$ Suharjana, 2018, p. 49). As a teacher, he must be able to be a good introduction to knowledge for his students, have innovation and be able to follow technological developments. In order for learning to be effective, a teacher must be able to manage the class well (Ningrum \& Sukoco, 2017, p. 172). The 
development of information, science, technology, art, culture is so rapid that it requires the readiness of all parties to be able to adapt to all existing conditions (Setyawan \& Lumintuarso, 2015, p. 209).

Concerning with the development of existing technology, people can assess the internet for learning with the use of E-learning. Internet enable learning combines teaching methods and technology as a means of learning. E-learning is an effective learning process that is produced by combining digital material delivery which consists of support and services in learning. In learning in the 21st century, elearning is a new form of pedagogy that supports the implementation of learning designed by lecturers or teachers. E-learning has the advantage that learning can be done flexibly, interactively. Blended learning or also known as hybrid learning is one example of e-learning that applies learning by combining online learning methods with face-to-face in the classroom directly. The use of the right method is an absolute necessity for a learning goal. The more suitable the method chosen in the learning process, the more effective the learning objectives will be (Prasetyo \& Sukarmin, 2017, p. 14).

Blended learning is not fully implemented online which replaces face-to-face interaction in class but it is can be applied to complement material that has not been conveyed in learning. Teachers use internet access to provide information or study materials for students. Asynchronous and synchronous communication is used by lecturers so that students can communicate with each other. Asynchronous communication is defined as instructions or communications that take place at different times and at different locations (Fenton \& Watkins, 2010: p.233). While synchronous is communication that occurs in real time.

There are three factors that influence student learning success: motivation, communication and blended learning design King \& Cerrone Arnold, (2012, p. 44). In addition, research by Herawati, Afriyati, Habibah, \& Pratiwi, (2020, p. 40) states that blended learning is effective in reducing learning saturation in lectures. Therefore, many schools and universities implement blended learning because of its advantages. The trend towards a mixed learning system will increase (Graham, 2006, p. 7). However, the success of implementing blended learning depends on several factors such as learning design. Blended learning must have a learning design that is attractive to users, easy to understand and able to facilitate interaction between students. This will have an influence on students' motivation to learn. In addition, the ability to manage blended learning with internet support is very important. A teacher must be able to manage blended learning independently, be able to operate easily and not experience internet problems. However, the learning outcomes of blended learning can still be debated because the success of blended learning from the side of users, managers and results does not occur automatically but is influenced by many factors (Yick, Yip, Au, Lai, \& Yu, 2019). In addition, the hours of deep learning also affect the understanding of the material presented in blended learning. Based on the explanation above, this study discuss the effect of blended learning, motivation, study hours on students' achievement.

\section{METHOD}

This research belongs to quantitative research. The research method used is the survey method. Survey research method is an investigation conducted to obtain certain facts from existing symptoms and to look for factual deficiencies. This study is a descriptive study, with the aim of describing the effect of blended learning, motivation, study hours on student achievement. The type of data used is quantitative data. The population in this study were the students of the PJKR FIK UNY Study Program and Bachelor Students of Physical Education, Putra Malaysia University (UPM). The determination of the sample in this study used a random sample (Cluster sampling). The study, which was conducted at UNY, had 221 research subjects with 80 women and 141 men, with a percentage of $36.19 \%$ female subjects and $63.81 \%$ male subjects. As for the UPM, there were 112 research subjects with 28 women and 84 men, with a percentage of $25 \%$ female subjects and $75 \%$ male subjects.

In order to measure students' motivation and learning hours this research employed a questionnaire. Meanwhile, learning achievement was gained from the course grade that applied blended learning. Further, the data that has been obtained in this study was analyzed. Data analysis in this study used descriptive statistics and inferential statistics with the help of computer programs. The results of descriptive statistical analysis point to the organization of the data. The data obtained were tabulated on each variable to find the average value, standard deviation, mode, median, minimum value and maximum value of each variable. The statistical test in this study used the Path Analysis test. 


\section{RESULT AND DISCUSSION}

\section{Percentage Of Uny Research Subjects}

The research subject involved in this research was 221 participants, consisted of 80 women and 141 men, with a percentage of $36.19 \%$ female subjects and $63.81 \%$ male subjects.
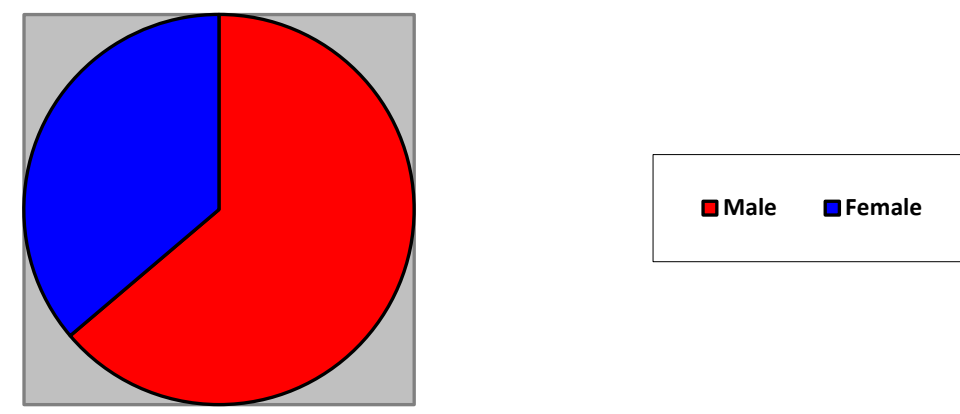

Figure 1. Percentage of UNY research sebjects

\section{Path Analysis Model 1}

Tabel 1. Model Summary

\begin{tabular}{lrrrrr}
\hline Model & R & R Square & Adjusted R Square & $\begin{array}{c}\text { Std. Error of the } \\
\text { Estimate }\end{array}$ & \multicolumn{1}{c}{ Durbin-Watson } \\
\hline 1 & $.754^{\mathrm{a}}$ & 0.569 & .565 & .33007 & 1.880 \\
\hline
\end{tabular}

A. Predictors: (Constant), Study hours, Blended Learning

B. Dependent Variable: Motivation

Tabel 2. Coefficients

\begin{tabular}{|c|c|c|c|c|c|c|}
\hline \multirow{2}{*}{\multicolumn{2}{|c|}{ Model }} & \multicolumn{2}{|c|}{ Unstandardized Coefficients } & \multicolumn{3}{|l|}{$\begin{array}{l}\text { Standardized } \\
\text { Coefficients }\end{array}$} \\
\hline & & B & Std. Error & Beta & $\mathrm{t}$ & Sig. \\
\hline \multirow[t]{3}{*}{1} & (Constant) & 1.216 & .136 & & 8.926 & .000 \\
\hline & Blended Learning & .407 & .044 & .502 & 9.342 & .000 \\
\hline & Study hour & .216 & .033 & .348 & 6.472 & .000 \\
\hline
\end{tabular}

A. Dependent Variable: Motivation

Path Coefficient Model I, it show's that the significance value of the two variables, X1 $=0.000$ and X2 $=0.000$ is smaller than 0.05. These results concluded that Regression Model I, namely variables $\mathrm{X} 1$ and $\mathrm{X} 2$ have a significant effect on $\mathrm{Y}$. Thus, the path diagram:

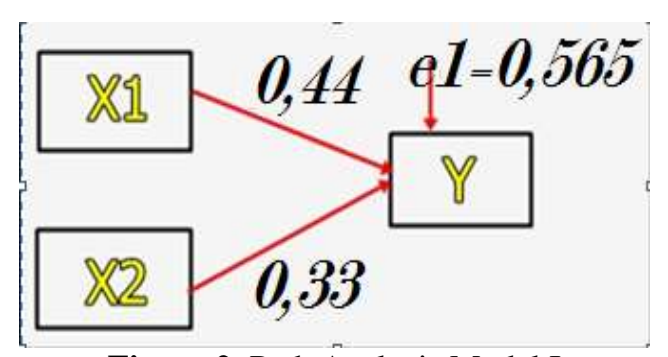

Figure 2. Path Analysis Model I

Description :

$\mathrm{X} 1=$ Blended Learning $(\mathrm{X} 1)$ 
Jurnal Keolahragaan 9 (2), 2021 - 171

Jaka Sunardi, Soh Kim Geok, Komarudin, Hari Yuliarto, Ranintya Meikahani

$\mathrm{X} 2=$ Study hours $(\mathrm{X} 2)$

$\mathrm{Y} \quad=$ Motivation $(\mathrm{Y})$

Path Analysis Model Ii

Tabel 3. Model Summary

\begin{tabular}{lrrrrr}
\hline Model & R & R Square & \multicolumn{2}{c}{$\begin{array}{c}\text { Adjusted R } \\
\text { Square }\end{array}$} & \multicolumn{2}{c}{$\begin{array}{c}\text { Std. Error of the } \\
\text { Estimate }\end{array}$} & Durbin-Watson \\
\hline 1 & $.239^{\mathrm{a}}$ & .57 & .044 & .11880 & 1.521 \\
\hline
\end{tabular}

A. Predictors: (Constant), Blended Learning, Study hours, Content attraction

B. Dependent Variable: Learning achievement

Tabel 4. Coefficients

\begin{tabular}{|c|c|c|c|c|c|c|}
\hline \multirow{2}{*}{\multicolumn{2}{|c|}{ Model }} & \multicolumn{2}{|c|}{ Unstandardized Coefficients } & \multirow{2}{*}{$\begin{array}{c}\text { Standardized } \\
\text { Coefficients } \\
\text { Beta } \\
\end{array}$} & \multirow[b]{2}{*}{$\mathrm{t}$} & \multirow[b]{2}{*}{ Sig. } \\
\hline & & $\mathrm{B}$ & Std. Error & & & \\
\hline \multirow[t]{4}{*}{1} & (Constant) & 3.608 & .049 & & 73.364 & .000 \\
\hline & Motivation & -.122 & .038 & -.678 & -3.182 & .002 \\
\hline & Study hours & .011 & .012 & .072 & .896 & .371 \\
\hline & Blended Learning & .103 & .044 & .526 & 2.364 & .008 \\
\hline
\end{tabular}

Path Coefficient Model II in the Coefficients table section, it is known that the significance value of the three variables, $\mathrm{X} 1=0.008, \mathrm{X} 2=0.371$ and $\mathrm{Y}=0.02$ is smaller than 0.05 . These results conclude that Regression Model II, the variables X1, X2 and Y have a significant effect on Z. Meanwhile for the value of e $2=(1-0.57)=0.655$. Thus the path diagram:

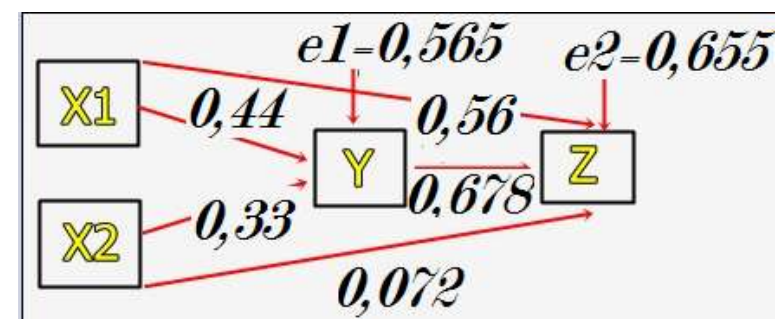

Description:

Figure 3. Path Analysis Model II

$\mathrm{X} 1 \quad=$ Blended Learning $(\mathrm{X} 1)$

$\mathrm{X} 2=$ Study hour $(\mathrm{X} 2)$

$\mathrm{Y} \quad=$ Motivation $(\mathrm{Y})$

$\mathrm{Z} \quad$ = Learning achievement $(\mathrm{Z})$

\section{The Steps of Testing Hypotheses And Conclusions}

The following is a description of the stages of hypothesis testing and conclusions. Analysis of the effect of $\mathrm{x} 1$ on $\mathrm{y}$ : it has been found that the significance value of $\mathrm{x} 1$ is $0.000<0.05$. This shows that there is a direct significant effect of $\mathrm{X} 1$ on Y. Analysis of the effect of $\mathrm{X} 2 \mathrm{on} \mathrm{Y}$ : the results show that the significance value of $\mathrm{X} 2$ is $0.000<0.05$. From these results it can be concluded that $\mathrm{X} 2$ has a direct significant effect on Y. Analysis of the influence of X1 on Z: the significance value of X1 is $0.008<0.05$. This shows that there is a direct significant effect of X1 on Z. Analysis of the influence of X2 on Z: the significance value of $\mathrm{X} 2$ is $0.371>0.05$. This shows that $\mathrm{X} 2$ has an indirect significant effect on $\mathrm{Z}$. Analysis of the influence of $\mathrm{Y}$ on $\mathrm{Z}$ : shows that the significance value of $\mathrm{Y}$ is $0.002<0.05$. This shows that there is a direct effect of $\mathrm{yYon} Z$. Analysis of the influence of $\mathrm{X} 1$ through $\mathrm{y}$ on Z: the direct effect 
of $\mathrm{X} 1$ on $\mathrm{Z}$ is 0.56 . The results showed that the indirect effect of $\mathrm{X} 1$ through $\mathrm{Y}$ on $\mathrm{Z}$ was the multiplication of the beta value of $x 1$ to $y$ with the beta value of $y$ to $\mathrm{z}$ : $0.44 \times 0.65=0.286$. The total value of the influence data given by $\mathrm{X} 1$ on $\mathrm{Z}$ is $056+0.286=0.846$. The direct influence value is 0.56 and the indirect effect is 0.286 . This shows that the value of the indirect effect is greater than the value of the direct effect, this result shows that $\mathrm{X} 1$ on $\mathrm{Y}$ indirectly has a significant effect on Z. Analysis of the influence of $\mathrm{X} 2$ through $\mathrm{y}$ on $\mathrm{z}$ : it is known that the direct effect given by $\mathrm{x} 2 \mathrm{on} \mathrm{z}$ is 0.072 . While the indirect effect of $\mathrm{x} 2$ through $\mathrm{y}$ on $\mathrm{z}$ is the multiplication of the beta value of $\mathrm{x} 2$ to $\mathrm{y}$ with the beta value of $\mathrm{y}$ to $\mathrm{z}: 0.33 \times 0.072=0.024$. Then the total effect given by $\mathrm{X} 2$ to $\mathrm{Z}$ is the direct effect plus the indirect effect: $0.072+0.024=0.095$. Based on the calculation results above, the direct influence value was 0.072 and the indirect effect was 0.024 , which means that the indirect effect value was greater than the direct influence value, this result indicated that $\mathrm{X} 2$ through $\mathrm{Y}$ indirectly has a significant effect on $\mathrm{Z}$ although it is weak.

\section{The Percentage Of Malaysia Research Subjects (Upm)}

The research involved 112 research subjects, consist of 28 women and 84 men, with a percentage of $25 \%$ female, and $75 \%$ male.

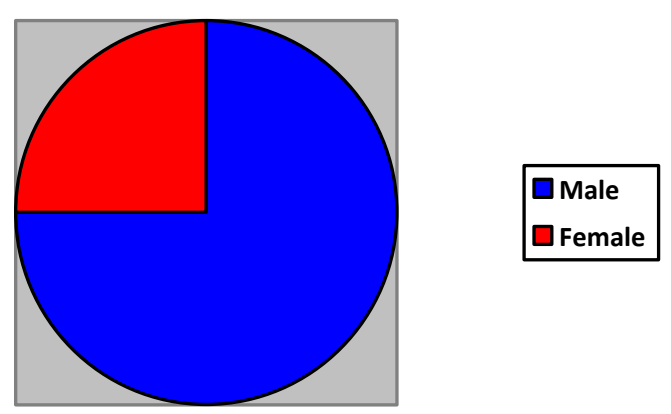

Figure 4. Percentage of research subject UPM

\section{Path Analysys Model 1}

Tabel 5. Model Summary

\begin{tabular}{|c|c|c|c|}
\hline Model & R Square & $\begin{array}{l}\text { Adjusted } \\
\text { R Square }\end{array}$ & $\begin{array}{l}\text { Std. } \\
\text { Error of } \\
\text { the } \\
\text { Estimate }\end{array}$ \\
\hline 1 & $\begin{array}{ll}.877^{\mathrm{a}} & 0.77 \\
\end{array}$ & 0.767 & 0.26576 \\
\hline \multicolumn{4}{|c|}{$\begin{array}{l}\text { A. Predictors: (Constant), Study hours X2, Blended } \\
\text { Learning X1 } \\
\text { B. Dependent Variable: Motivation Y }\end{array}$} \\
\hline
\end{tabular}

Tabel 6. Coefficients

\begin{tabular}{rlccccr}
\hline \multirow{2}{*}{ Model } & \multicolumn{5}{c}{ Unstandardized } \\
Coefficients & \multicolumn{2}{c}{$\begin{array}{c}\text { Standardized } \\
\text { Coefficients }\end{array}$} & T & Sig. \\
\hline & B & $\begin{array}{c}\text { Std. } \\
\text { Error }\end{array}$ & Beta & & \\
\hline & $\begin{array}{l}\text { (Constant) } \\
\text { Blended }\end{array}$ & 0.317 & 0.148 & & 2.138 & 0.034 \\
$\begin{array}{l}\text { Learning } \\
\text { X1 } \\
\text { Study } \\
\text { hours X2 }\end{array}$ & 0.621 & 0.036 & 0.664 & 17.102 & 0 \\
\hline
\end{tabular}

a. Dependent Variable:

Motivation Y 
Path Coefficient Model I show's that the significance value of the two variables, $\mathrm{X} 1=0.000$ and $\mathrm{X} 2=0.000$, is smaller than 0.05 . It can be concluded that the regression model, variables $\mathrm{X} 1$ and $\mathrm{X} 2$ have a significant effect on Y. Meanwhile, the value of e 1 can be obtained with the use of formula e1 = $(1-0.77)=0.479$. Thus, the path diagram:

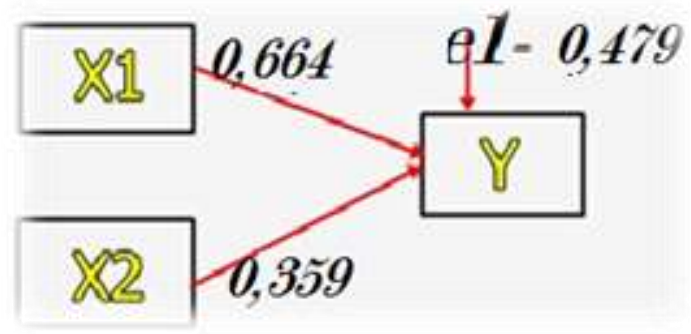

Description:

Figure 5. Path Analysis Model I

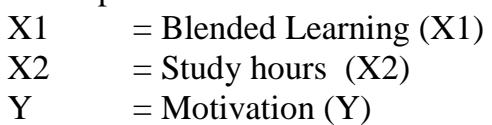

Path Analysys Model 2

Table 7. Model Summary

\begin{tabular}{lcccc}
\hline Model & R & R Square & Adjusted R Square & $\begin{array}{c}\text { Std. Error of the } \\
\text { Estimate }\end{array}$ \\
\hline 1 & $.778^{\text {a }}$ & .605 & .594 & .23895 \\
\hline a. Predictors: (Constant), Study hours X2, Blended Learning X1, Motivation \\
Y
\end{tabular}

Tabel 8. Coefficients

\begin{tabular}{|c|c|c|c|c|c|c|}
\hline \multirow{2}{*}{\multicolumn{2}{|c|}{ Model }} & \multicolumn{2}{|c|}{ Unstandardized Coefficients } & \multicolumn{3}{|l|}{$\begin{array}{l}\text { Standardized } \\
\text { Coefficients }\end{array}$} \\
\hline & & $\mathrm{B}$ & Std. Error & Beta & $\mathrm{T}$ & Sig. \\
\hline \multirow[t]{4}{*}{1} & (Constant) & 1.580 & .173 & & 9.153 & 0.000 \\
\hline & Blended Learning X1 & .300 & .072 & 0.469 & 4.176 & 0.000 \\
\hline & Motivation Y & .192 & .091 & 0.283 & 2.111 & 0.037 \\
\hline & Study hours X2 & .048 & .046 & 0.089 & 1.046 & 0.298 \\
\hline
\end{tabular}

Path Coefficient Model II, it was known that the significance value of the three variables, $\mathrm{X} 1=$ $0.00, \mathrm{X} 2=0.037$ and $\mathrm{Y}=0.037$ was smaller than 0.05 . The variables $\mathrm{X} 1, \mathrm{X} 2$ and $\mathrm{Y}$ have a significant effect on Z. The value of R2 or R Square was 0.60 , this indicated that the contribution of $0 \mathrm{X} 1, \mathrm{X} 2$ and $\mathrm{Y}$ to $\mathrm{Z}$ is $60 \%$ while the remaining $43 \%$ is a contribution from other variables not examined. Meanwhile for the value of e $2=(1-0.60)=0.774$. Thus, the path diagram:

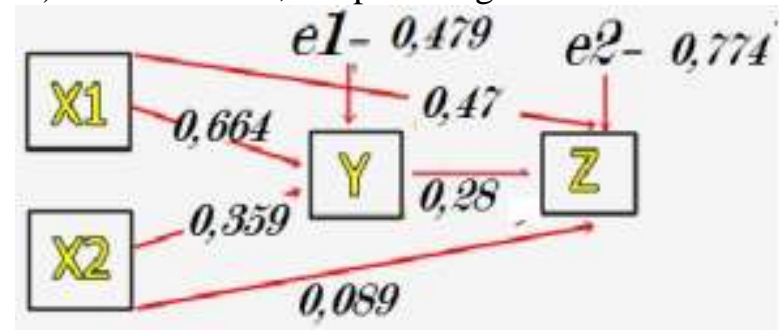

Figure 6. Path Analysis Model II

$\mathrm{X} 1=$ Blended Learning $(\mathrm{X} 1)$

$\mathrm{X} 2=$ Study Hours $(\mathrm{X} 2)$

$\mathrm{Y} \quad=$ Motivation $(\mathrm{Y})$

$\mathrm{Z} \quad$ = Learning Achievement

The Steps Of Testing Hypotheses And Conclusions 
The following is the stage of testing the hypothesis and making conclusions in this study with the subject of UPM Malaysia students. Analysis of the effect of X1 on Y: the significance value of X1 is $0.000<0.05$. This shows that $\mathrm{X} 1$ has a direct significant effect on $\mathrm{Y}$. Analysis of the effect of $\mathrm{X} 2$ on $\mathrm{Y}$ : the significance value of $\mathrm{X} 2$ is $0.00<0.05$. This shows that there is a direct significant effect of $\mathrm{X} 2$ on $\mathrm{Y}$. Analysis of the influence of $\mathrm{X} 1$ on $\mathrm{Z}$ : the significance value of $\mathrm{X} 1$ is $0.00<0.05$. This shows that there is a direct significant effect of $\mathrm{X} 1$ on Z. Analysis of the influence of X2 on Z: the significance value of $\mathrm{X} 2$ is $0.29>0.05$. This shows that there is a significant indirect effect of $\mathrm{X} 2$ on $\mathrm{Z}$. Analysis of the influence of $Y$ on $Z$ : the significance value of $Y$ is $0.037<0.05$. Analysis of the Effect of $X 1$ through $\mathrm{Y}$ on $\mathrm{Z}$ : the direct effect of $\mathrm{X} 1$ on $\mathrm{Z}$ is 0.47 . While the indirect effect of $\mathrm{X} 1$ through $\mathrm{Y}$ on $\mathrm{Z}$ is the multiplication between the beta value of $\mathrm{X} 1$ to $\mathrm{Y}$ with the beta value of $\mathrm{Y}$ to $\mathrm{Z}: 0.664 \times 0.28=0.185$. Then the total effect given by $\mathrm{X} 1$ to $\mathrm{Z}$ is the direct effect plus the indirect effect: $0.47+0.185=0.655$. These results indicated that $X 1$ through $Y$ directly has a significant effect on $Z$. Analysis of the influence of $\mathrm{X} 2$ through $\mathrm{Y}$ on $\mathrm{Z}$ : it was known that the direct effect given by $\mathrm{X} 2$ to $\mathrm{Z}$ was 0.089 . While the indirect effect of $\mathrm{X} 2$ through $\mathrm{Y}$ on $\mathrm{Z}$ was the multiplication between the beta value of $\mathrm{X} 2$ against $\mathrm{Y}$ with the beta value of $Y$ against $Z: 0.359 \times 0.089=0.031$. Then the total effect given by $\mathrm{X} 2$ to $Z$ was the direct effect plus the indirect effect: $0.089+0.031=0.12$. Based on the results of the calculations above, the direct influence value was 0.089 and the indirect effect was 0.031 , which means that the direct influence value was greater than the indirect effect value, these results indicated that X2 through Y directly has a significant effect on $\mathrm{Z}$.

\section{DISCUSSION}

The effect of blended learning on student learning motivation. Based on the results of research with the subject of UNY and UPM students, it was found that a significance value of $0.000<0.05$ was obtained on learning motivation. This shows that blended learning on students' learning motivation has a significant influence. It shows that there is a direct effect of blended learning on student learning motivation, according to research that has been carried out by (Syarif, 2013, p. 234). In addition, research on the effectiveness of e-learning models on Algorithm and Programming lectures shows that there are differences in student learning motivation between blended learning models and conventional models of 5,782 and differences in understanding levels of 9,935 and there is an increase in learning motivation due to blended learning models on average. the average increase is 11,705 and there is an average increase in student understanding of 30,288 (Sarah Bibi, 2015, p. 74). This shows an increase in student learning motivation due to the application of blended learning.

There is a direct influence of study hours on student motivation. Based on the results of research with UNY and UPM students, the significance value of study hours was $0.00<0.05$. It shows that there was a direct significant effect of study hours on student motivation. If the individual wants to excel, then he will give his best effort through the energy of achievement (Blegur \& Mae, 2018, P. 31), this can be seen from the student's study hours.

The effect of blended learning on student achievement. The significance value of the data from UNY students was $0.008<0.05$. There was a direct significant effect of blended learning on student achievement. Meanwhile, the significance value from UPM was of $0.00<0.05$. There was a direct significant effect of blended learning on learning achievement. This is in line with the results of Utami's research (2018, p. 42) which used experimental research methods with a randomized control group pretest-posttest design. The study showed that the learning outcomes of the experimental group were higher than those of the control groups. So, it can be concluded that blended learning model contributes more to student achievement.

The effect of study hours on student achievement. From UNY student data, it was obtained a significance value: $0.371>0.05$. Meanwhile, for UPM students, a significance value was $0.29>0.05$. There was a significant effect of study hours on learning achievement for UNY and UPM students. Study hours are related to the continuity of the learning process, where the learning process is important in producing achievements (Putra \& Sugiyanto, 2016, p. 179).

The effect of motivation on student achievement. The data that has been obtained from UNY shows the significance value of $0.002<0.05$. There was a direct significant influence of motivation on student achievement. Meanwhile, for UPM students, a significance value of $0.037<0.05$ was obtained. There was a direct significant effect of motivation on student achievement. The concept that discusses 
desire, drive, will and interest is motivation. As stated in Syaukani, Subekti, \& Fatoni, (2020, p. 122) that a person who shows displays characteristics such as having high enthusiasm and passion to do something, and trying to achieve achievement. Motivation is an impulse that is closely related to how to do something well to achieve success (Dahlan, Hidayat, \& Syahruddin, 2020, p. 136). Therefore, the higher a person's motivation, the more influential it is on student achievement.

The effect of blended learning through motivation on student achievement. The significance value of UNY students was 0.56. It means the direct effect given by blended learning on student achievement was 0.56 . While the indirect effect of blended learning through motivation on student learning achievement was the multiplication between the beta values of blended learning on motivation and the beta value of motivation on student achievement was $0.44 \times 0.65=0.286$. So, the total effect given by blended learning on student achievement was the direct effect plus the indirect effect was 056 $+0.286=0.846$. Meanwhile, the data obtained from UPM students showed a significant value of the direct influence given by blended learning on learning achievement of 0.47. As stated (Syahruddin, Saleh, \& Saleh, 2019, p. 94), that in the learning process the teacher's role greatly influences the results of the learning process itself. In this case, through blended learning, the teacher plays a role in increasing the motivation of students to produce good learning achievements.

The effect of study hours through motivation on learning achievement. Based on the calculations in this study, data has been obtained that the subject of UNY students is known to have an indirect influence value greater than the direct influence value, these results indicate that indirectly learning hours through motivation have a significant effect on learning achievement even though it is weak. While the subject of upm students means that the value of direct influence is greater than the value of indirect influence, these results indicate that learning hours directly through motivation have a significant effect on learning achievement. This shows that there is an effect of study hours through motivation on learning achievement, although there are direct and indirect effects for the two research subjects.

\section{CONCLUSION}

Based on the results of the research, it can be concluded that (1) There is a significant effect between blended learning on motivation for both UNY and UPM students, (2) There is a significant effect between blended learning on study hours for both UNY and UPM students, (3) There is a significant effect between blended learning on study hours for both UNY and UPM students, (4) There is effect between blended learning on UNY students' learning achievement although it is weak, this shows that learning achievement is influenced by other variables that was not examined. As for UPM, there is a significant effect but for the learning achievement variable it is influenced by other variables not examined, (5) There is a multiple influence between blended learning, motivation, and study hours for UNY and UPM students, however the learning achievement variable is influenced by other factors that was not examined in this study. Therefore, further research is needed to find out more about other variables that affect blended learning on learning achievement.

Blended learning, motivation, and study hours have an influence on student achievement. Interesting blended learning content can increase student learning motivation. Students can also determine learning, can remember the time and study time with more flexible mixed learning. Thus, blended learning, motivation and study hours have an influence on student learning outcomes in sports. Further research is needed to find out more about other variables that affect blended learning on learning achievement. 


\section{Jurnal Keolahragaan 9 (2), 2021 - 176}

Jaka Sunardi, Soh Kim Geok, Komarudin, Hari Yuliarto, Ranintya Meikahani

\section{REFERENCES}

Blegur, J., \& Mae, R. M. (2018). Motivasi berolahraga atlet atletik dan tinju Sport motivation of athletic and boxing athleetes. Jurnal Keolahragaan, 6(1), 29-37.

Dahlan, F., Hidayat, R., \& Syahruddin, S. (2020). Pengaruh komponen fisik dan motivasi latihan terhadap keterampilan bermain sepakbola. Jurnal Keolahragaan, 8(2), 126-139.

https://doi.org/10.21831/jk.v8i2.32833

Fenton \& Watkins. (2010). Fluency in distance learning. Charlotte, NC: Information age publishing, Inc.

Graham. (2006). Blended learning systems: Definition, current trends, and future directions. In C. J. Bonk \& C. R. Graham (Eds), The Handbook of blended learning: Global perspectives, local designs (pp.3-21). San Francisco, CA: John Wiley \& Sons, Inc.

Herawati, A. A., Afriyati, V., Habibah, S., \& Pratiwi, C. (2020). Efektifitas Penggunaan Media Pembelajaran Berbasis Blended Learning untuk Mengurangi Burnout Belajar Pada Perkuliahan Bimbingan dan Konseling Keluarga di Prodi Bimbingan dan Konseling Universitas Bengkulu. Educational Guidance and Counseling Development Jounal, 3(2), 40-48.

King, S. E., \& Cerrone Arnold, K. (2012). Blended Learning Environments in Higher Education: A Case Study of How Professors Make it Happen. Mid-Western Educational Researcher, 25(1/2), 44-59. Retrieved from http://0-

search.ebscohost.com.library.vu.edu.au/login. aspx $?$ direct $=$ true $\& d b=e h h \& A N=94769319 \&$ site $=e$ host-live

Ningrum, N. F. M., \& Sukoco, P. (2017). Pengembangan model permainan untuk meningkatkan perseptual motorik dan perilaku sosial siswa sekolah dasar kelas bawah. Jurnal Keolahragaan, 5(2), 171. https://doi.org/10.21831/jk.v5i2.7905

Pambudi, D. K., \& Suharjana, S. (2018). Pengembangan video pembelajaran sinyal-sinyal wasit bola basket untuk guru penjasorkes sekolah menengah atas. Jurnal Keolahragaan, 6(1), 48-59. https://doi.org/10.21831/jk.v6i1.11880

Prasetyo, D. W., \& Sukarmin, Y. (2017). Pengembangan model permainan untuk pembelajaran teknik dasar bola basket di SMP. Jurnal Keolahragaan, 5(1), 12. https://doi.org/10.21831/jk.v5i1.12758

Putra, G. I., \& Sugiyanto, F. (2016). Pengembangan pembelajaran teknik dasar bulu tangkis berbasis multimedia pada atlet usia 11 dan 12 tahun. Jurnal Keolahragaan, 4(2), 175. https://doi.org/10.21831/jk.v4i2.10893

Rivalina, R. (2005). Strategi Pemanfaatan Sumberdaya. Kwangsan, 5(2), 129-145.

Sarah Bibi, H. J. (2015). Efektivitas Model Blended Learning Terhadap Kuliah Algoritma Dan Pemrograman. Jurnal Pendidikan Vokasi, 5(2), 74-87.

Selwyn, N., \& Husen, O. (2010). The educational benefits of technological competence: an investigation of students' perceptions. Evaluation \& Research in Education, 23(2), 137-141. https://doi.org/10.1080/09500790.2010.483515

Setyawan, K. A., \& Lumintuarso, R. (2015). Model Pengenalan Permainan Dalam Pembelajaran Lompat Jauh Pada Siswa Kelas Atas Sekolah Dasar. Jurnal Keolahragaan, 3(2), 208-217. https://doi.org/10.21831/jk.v3i2.6245

Sucipto, E., \& Widiyanto, W. (2016). Jurnal Keolahragaan. Pengembangan Model Pembelajaran Lempar Lembing Untul Siswa Sekolah Menengah Pertama(Smp), 4(April), 111-121. Retrieved from vfile:///C:/Users/ACER/Downloads/pdf latihan beban dan kekuatan otot.pdf

Syahruddin, S., Saleh, M. S., \& Saleh, M. S. (2019). The influence of kinesthetics, attitude and motivation on the learning results of sports education. Jurnal SPORTIF : Jurnal Penelitian Pembelajaran, 5(2), 232. https://doi.org/10.29407/js_unpgri.v5i2.12871 
Syarif, I. (2013). Pengaruh model blended learning terhadap motivasi dan prestasi belajar siswa SMK. Jurnal Pendidikan Vokasi, 2(2), 234-249. https://doi.org/10.21831/jpv.v2i2.1034

Syaukani, A. A., Subekti, N., \& Fatoni, M. (2020). Analisis tingkat motivasi belajar dan berlatih pada atlet-pelajar PPLOP Jawa Tengah tahun 2020. Jurnal Keolahragaan, 8(2), 117-125. https://doi.org/10.21831/jk.v8i2.32553

Utami, I. S. (2018). The Effectiveness of Blended Learning as an Instructional Model in Vocational High School. Journal of Educational Science and Technology (EST), 4(1), 74. https://doi.org/10.26858/est.v4i1.4977

Yick, K., Yip, J., Au, S., Lai, Y., \& Yu, A. (2019). Effectiveness of blended learning in the first year of fashion education. International Journal of Fashion Design, Technology and Education, 12(2), 178-188. https://doi.org/10.1080/17543266.2018.1546910 